\title{
Composition and ecology of deep-water coral associations
}

\author{
D. H. H. Kühlmann \\ Museum für Naturkunde, Humboldt-Universität Berlin; \\ Invalidenstr. 43, DDR-1040 Berlin, German Democratic Republic
}

\begin{abstract}
Between 1966 and 1978 SCUBA investigations were carried out in French Polynesia, the Red Sea, and the Caribbean, at depths down to $70 \mathrm{~m}$. Although there are fewer coral species in the Caribbean, the abundance of Scleractinia in deep-water associations below $20 \mathrm{~m}$ almost equals that in the Indian and Pacific Oceans. The assemblages of corals living there are described and defined as deep-water coral associations. They are characterized by large, flattened growth forms. Only 6 to $7 \%$ of the species occur exclusively below $20 \mathrm{~m}$. More than $90 \%$ of the corals recorded in deep waters also live in shallow regions. Depth-related illumination is not responsible for depth differentiations of coral associations, but very likely, a complex of mechanical factors, such as hydrodynamic conditions, substrate conditions, sedimentation etc. However, light intensity determines the general distribution of hermatypic Scleractinia in their bathymetric range as well as the platelike shape of coral colonies characteristic for deep water associations. Depending on mechanical factors, Leptoseris, Montipora, Porites and Pachyseris dominate as characteristic genera in the Central Pacific Ocean, Podabacia, Leptoseris, Pachyseris and Coscinarea in the Red Sea, Agaricia and Leptoseris in the tropical western Atlantic Ocean.
\end{abstract}

\section{INTRODUCTION}

Considerable attention has been paid to shallow-water coral associations since the first half of this century (Duerden, 1902; Mayer, 1918; Umbgrove, 1939). Detailed investigations at depths down to $20 \mathrm{~m}$ became possible only through the use of autonomous diving apparatus. SCUBA diving encounters limitations at greater depths due to technical, physiological and methodological problems, and only few studies have been conducted at depths exceeding $30 \mathrm{~m}$ (Roos, 1964; Pichon, 1972, 1977; Goreau \& Goreau, 1973; Goreau \& Land, 1974; Kühlmann, 1974a; Bak, 1977; Sheppard, 1980, 1981). SCUBA techniques provide the most detailed and precise method for investigating composition and ecology of deep-water coral associations.

\section{METHODS}

Steep slopes with relatively monotonous surfaces of coral reefs were chosen as study sites in order to avoid complications due to bottom unevenness. The investigations were carried out between the water surface and $70 \mathrm{~m}$ depth, employing standard SCUBA techniques.

Hermatypic corals were collected in order to facilitate taxonomic determination. 
Data on depth occurrence, listed in tables without references, were extracted from publications by Klunzinger (1879), Quelch (1886), Gardiner (1898, 1904, 1905), Vaughan (1907, 1918), Mayer (1918), Horst (1922), Matthai (1924), Hoffmeister (1925), Thiel (1932), Umbgrove (1940), Crossland (1952), Wells (1954, 1971, 1973), Goreau \& Wells (1967), Chevalier (1971, 1975), Wijsman-Best $(1972,1977)$, Yamazato (1972), Goreau \& Goreau (1973), Scheer \& Pillai (1974), Pillai \& Scheer (1976), Veron \& Pichon (1976, 1979), Scatterday (1977), Veron, Pichon \& Wijsman-Best (1977), Faure \& Pichon (1978), Rosen (1978), Wallace (1978), Dinesen (1980), Zlatarski \& Estalella (1982). Uncertain data regarding maximum depths (obtained by dredging) are represented in the form of dotted lines. Only definite values based on own visual observations have been expressed as straight lines. Values taken from literature are expressed by dashes in Tables 4 and 5 . Data on depth occurrence reported in the literature could be complemented in 71 cases.

\section{DEEP-WATER CORAL ASSOCIATIONS}

My results are presented here from East to West, i.e. in the order Pacific Ocean, Red Sea, western Atlantic Ocean.

Tak a poto is a flat atoll covered by coconut palms. It belongs to the Tuamotu Archipelago situated $145^{\circ} 10^{\prime} \mathrm{W}$ and $14^{\circ} 40^{\prime} \mathrm{S}$. Its outer slopes fall sharply to a depth of more than $2500 \mathrm{~m}$. Its lagoon measures $6 \times 20 \mathrm{~km}$, and is more than $30 \mathrm{~m}$ deep. The lagoon contains some patch reefs, either isolated or arranged in groups. Takapoto is a purely oceanic coral atoll, affected neither by terrigenous nor by local anthropogenic

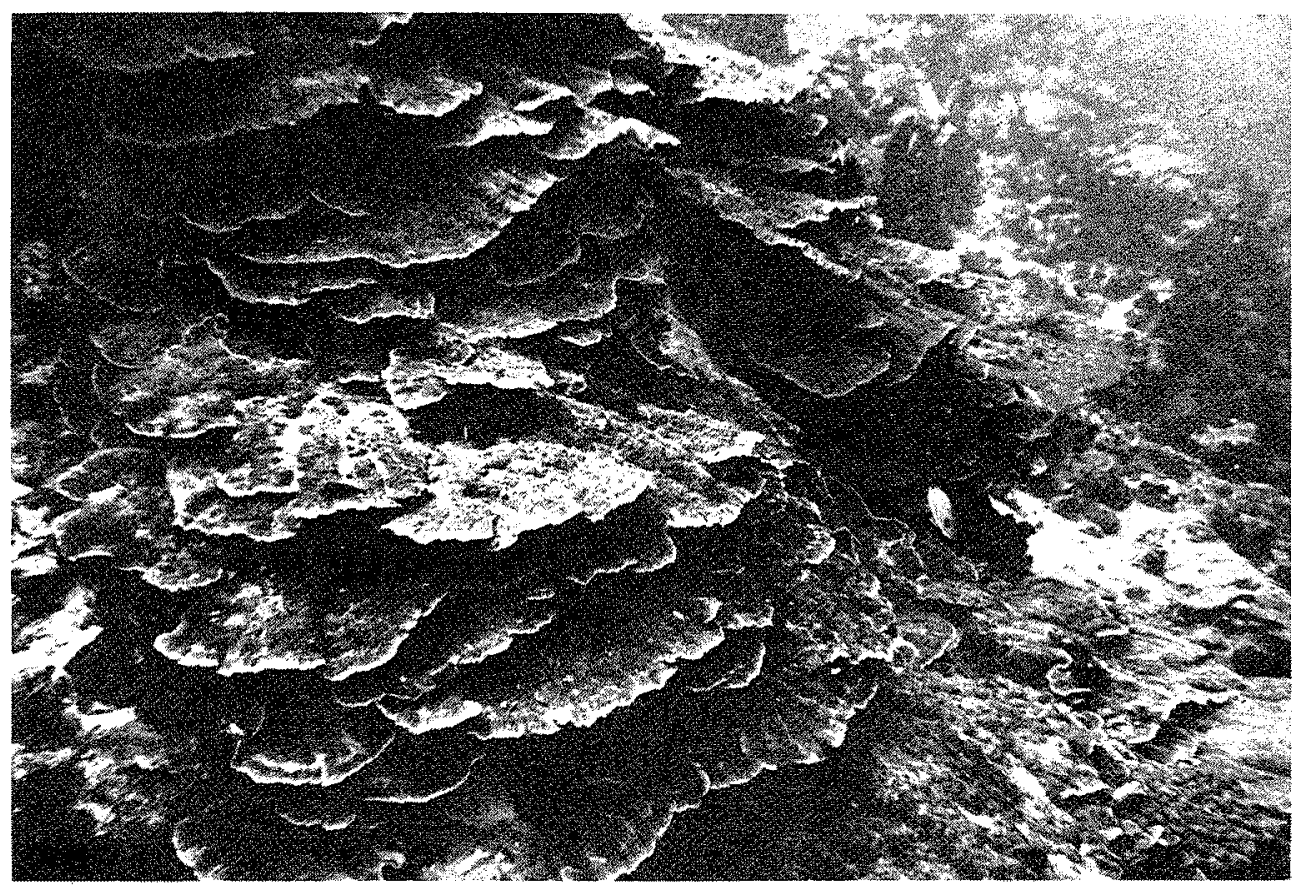

Fig. 1. On the leeward slope, in calm waters $(25-30 \mathrm{~m}$ deep), Synarea convexa with its large, flattened, deep-water shape is predominant. Takapoto Atoll, Tuamotus. (Photo: D. H. H. Kühlmann) 
substances. I have studied both the windward and leeward sides of the outer atoll slopes and patch reefs in the lagoon. At first, the windward side slopes gradually from the shore seawards, then, at a depth of 20 to $25 \mathrm{~m}$, steeply at an angle of $60^{\circ}$. The leeward slope starts to fall at an angle of 50 to $90^{\circ}$ from 12 to $15 \mathrm{~m}$. Both slopes are characterized by good and comparable light and visibility conditions: at a depth of $20 \mathrm{~m}$, visibility is $40 \mathrm{~m}$; at $40 \mathrm{~m}, 20 \mathrm{~m}$; at $50 \mathrm{~m}, 12 \mathrm{~m}$; at $70 \mathrm{~m}, 5 \mathrm{~m}$ (Kühlmann, 1970b). However, the plateshaped colonies of Synaraea and Leptoseris dominate on the leeward slope (Fig. 1), while the windward slope is dominated by Porites and Montipora colonies which are flattened like shingles (Fig. 2). This remarkable difference will be discussed later.

The water in the lagoon differs from that in the open ocean: it has a higher salinity, due to higher evaporation (Caspers, 1968, 1981; Hauti, pers. comm.); it is wind-protected and therefore less intermixed; it contains heavy suspensions and is more turbid. Hence, except the 3 euryoecious species Acropora cf. valida, Pavona varians and Porites australiensis, all others occur either on the outer slopes or in the lagoon. There are also differences in the composition of the coral associations on the outer slopes: 16 species were found in both habitats; 7 species were found exclusively on the windward sloper and 10 exclusively on the leeward slope. Table 1 lists the composition of the Takapoto deep-water coral associations of the outer slopes leeward (Fig. 1) and windward (Fig. 2) and of the patch reefs in the lagoon.

Mo or e a lies in the vicinity of Tahiti. It is one of the Society Islands and is located

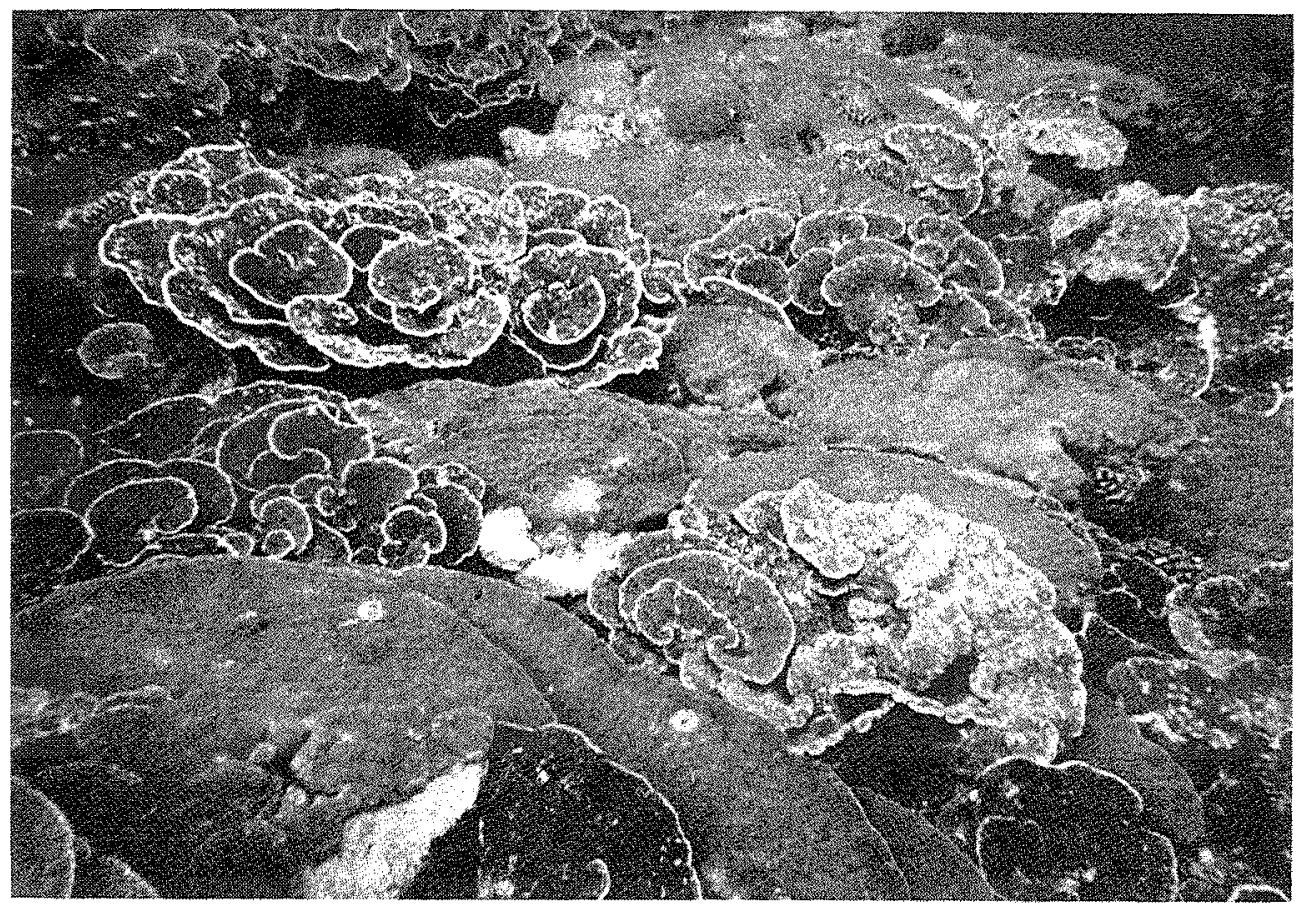

Fig. 2. On the windward slope with its strong water movement a deep-water coral association grows at a depth of $25 \mathrm{~m}$ with flattened Porites australiensis, Montipora verrilli and some branched Pocillopora verrucosa. Takapoto Atoll, Tuamotus. (Photo: D. H. H. Kühlmann) 
$149^{\circ} 50^{\prime} \mathrm{W}$ and $17^{\circ} 30^{\prime} \mathrm{S}$. Of volcanic origin, it consists of a large crater whose northern part has collapsed and sunk beneath the water surface (Chevalier, 1973). Although it measures only about $23 \times 30 \mathrm{~km}$, the peak of its jagged crater crown is as high as $1212 \mathrm{~m}$. The ocean around the island is more than $1500 \mathrm{~m}$ deep. The island is encircled by a barrier reef, the sides of which slope down more or less steeply to 30 to $40 \mathrm{~m}$, abutting on a bottom covered with sand and debris. The steep slope continues to depths

Table 1. Deep-water coral associations of the Takapoto Atoll, Tuamotus, Pacific; $+=20$ to $40 \mathrm{~m}$ deep $_{i}>=$ deeper than 40 to $70 \mathrm{~m}$

\begin{tabular}{|c|c|c|c|}
\hline \multirow[b]{2}{*}{ Species } & \multicolumn{2}{|c|}{ Outer slope } & \multirow[b]{2}{*}{ Lagoon } \\
\hline & Windward & Leeward & \\
\hline Porites australiensis Vaughan, 1918 & + & $+>$ & + \\
\hline Leptastrea transversa Klunzinger, 1879 & + & $+>$ & + \\
\hline Acropora cf. valida (Dana, 1846) & + & + & + \\
\hline Astreopora myriophthalma (Lamarck, 1816) & + & $+>$ & \\
\hline Pavona varians Verrill, 1864 & + & $+>$ & \\
\hline Fungia concinna Verrill, 1864 & + & $+>$ & \\
\hline Millepora platyphylla Ehrenberg, 1834 & + & + & \\
\hline Pocillopora elegans Dana, 1846 & + & + & \\
\hline Pocillopora verrucosa (Ellis et Solander, 1786) & + & + & \\
\hline Montipora verrilli Vaughan, 1907 & + & + & \\
\hline Leptoseris incrustans (Quelch, 1886) & + & + & \\
\hline Pavona clavus (Dana, 1846) & + & + & \\
\hline Herpolitha limax (Esper, 1797) & + & + & \\
\hline Porites lutea Edwards et Haime, 1851 & + & + & \\
\hline Favia stelligera (Dana, 1846) & + & + & \\
\hline Acanthastrea echinata (Dana, 1846) & + & + & \\
\hline Leptoseris mycetoseroides Wells, 1954 & + & & \\
\hline Pachyseris speciosa (Dana, 1846) & + & & \\
\hline Porites lichen Dana, 1846 & + & & \\
\hline Echinopora cf. lamellosa (Esper, 1795) & + & & \\
\hline Echinophyllia aspera (Ellis et Solander, 1786) & + & & \\
\hline Leptoseris porosa (Quelch, 1886) & $>$ & & \\
\hline Fungia cf. granulosa Klunzinger, 1879 & $>$ & & \\
\hline Pocillopora cf. solida Quelch, 1886 & & $+>$ & \\
\hline Synaraea convexa Verrill, 1864 & & $+>$ & \\
\hline Acropora danai (Edwards et Haime, 1860) & & + & \\
\hline Acropora nasuta (Dana, 1846) & & + & \\
\hline Acropora rambleri (Basset-Smith, 1890) & & + & \\
\hline Montipora cf. tuberculosa (Lamarck, 1816) & & + & \\
\hline Gardineroseris planulata (Dana, 1846) & & + & \\
\hline Leptoseris fragilis Edwards et Haime, 1849 & & + & \\
\hline Pavona maldivensis (Gardiner, 1905) & & + & \\
\hline Fungia paumotensis Stutchbury, 1833 & & + & \\
\hline Stylocoeniella guentheri Bassett-Smith, 1890 & & & + \\
\hline Psammocora cf. contigua (Esper, 1797) & & & + \\
\hline Montipora verrucosa (Lamarck, 1816) & & & + \\
\hline Favia speciosa (Dana, 1846) & & & + \\
\hline Leptastrea purpurea (Dana, 1846) & & & + \\
\hline Platygyra daedalea (Ellis et Solander, 1786) & & & + \\
\hline Lobophyllia corymbosa (Forskal, 1775) & & & + \\
\hline
\end{tabular}


of more than $60 \mathrm{~m}$ where passages in front of river mouths cause a break in the barrier reef. The steep slopes of the patch reefs in the lagoon reach depths of 20 to $30 \mathrm{~m}$. In the northeastern corner of the island, the barrier reef has become a fringing reef (Chevalier, 1977). Coral associations of the seaward slope have grown along the northern barrier reef which, in its central part, is relatively well protected from the wind, although it is exposed to strong-to-moderate currents. Currents are stronger in the northwestern and, in particular, northeastern waters. The slopes incline, in many different ways, towards the sea at angles of 5 to $35^{\circ}$ forming reef tongues. Dominant shrubby growth forms extend far down. Typical flattened deep-water coral associations become - at first gradually then increasingly - intermingled with shallow-water forms at $30 \mathrm{~m}$. Terrigenous suspensions from rivers and brooks as well as increasing depths reduce light and visibility: it is $20 \mathrm{~m}$ at $20 \mathrm{~m}$ depth; $10 \mathrm{~m}$ at $40 \mathrm{~m}$, and $5 \mathrm{~m}$ at $50 \mathrm{~m}$. Corals at a depth of 40 to $50 \mathrm{~m}$ stem from rubble plains of the sandy zone in front of the reef which have a seaward inclination of 7 to $10^{\circ}$. Of the 35 species occurring on the outer slope of the barrier reef at a depth of 30 or $40 \mathrm{~m}, 15$ species also live in the rubble zone of the fore reef.

The lagoon behind the barrier reef is influenced by the sea entering it by several channels. This is perhaps the reason why 28 of a total of 43 species live both on the outer slope and in the lagoon. The 3 species found only on the patch reefs of the lagoon of Moorea are Psammocora explanulata, $P$. nierstraszi and $P$. cf. obtusangula. Considering the presence of $P$. cf. contigua in the lagoon of Takapoto, the genus Psammocora seems to be particularly adapted to this habitat; if so, $P$. profundacella, which I found only on the outer slope of Moorea, is a biological exception to this rule. Table 2 lists the diversity of the deep-water coral associations below $20 \mathrm{~m}$ in the open sea and in the lagoon of Moorea.

Wing a te Reef, $37^{\circ} 18^{\prime} \mathrm{E}$ and $19^{\circ} 38^{\prime} \mathrm{N}$, is situated 3 nautical miles northeast of Port Sudan in the Red Sea and extends about $8 \mathrm{~km}$ in a northeasterly direction. It follows the contours of the coast, north of Port Sudan. It is a barrier reef which has grown on a mountain crest. Forming several terraces, its outer slope inclines seawards to depths of more than $700 \mathrm{~m}$, and landwards down to $413 \mathrm{~m}$. Its eastbound outer slope at first falls to a depth of 18 to $22 \mathrm{~m}$ in an irregular fashion, then continues falling steeply as a vertical or slightly overhanging rock wall. An overhanging ledge at its bottom is covered with Gorgonacea hanging downwards. At 30 to $35 \mathrm{~m}$ a slope with an inclination of $60^{\circ}$ extends into a depth of 70 to $80 \mathrm{~m}$, and then again falls vertically. A slight current flows from north to south in accordance with the main wind direction. The water is clear and well illuminated due to an almost constantly cloudless sky.

While the perpendicular wall is only sparsely covered with corals, the steep slope underneath at first displays a much denser abundance, followed abruptly by an area nearly clear of corals from $50 \mathrm{~m}$ onward. While the sparse colonization of the rock wall is due to the vertical or slightly, overhanging substrate, unsuitable for coral growth, the abrupt reduction in abundance below $50 \mathrm{~m}$ is possibly due to a general reduction of light intensity to below the minimum necessary, accompanied by a thermocline at that depth and a drop in water temperature from 31 to $28^{\circ} \mathrm{C}$ in August. With 52 species occurring below $20 \mathrm{~m}$, the diversity of species is fairly high (Table 3). One of the two Stylophora species, St. mamillata, occurs at depths between 20 and $40 \mathrm{~m}$; the other, St. kuehlmanni, between 20 and $70 \mathrm{~m}$. Both are typical components of local deep-water coral associa- 
tions. However, in general, the foliaceous or disk-shaped forms of Leptoseris, Coscinarea, Mycedium, Pachyseris, Pavona, Podabacia, Echinopora, Echinophyllia and the crustose colonies of Psammocora, Montipora, Porites, Favia, Favites and Leptastrea were dominant.

Table 2. Deep-water coral associations of Moorea, Society Islands, Pacific

\begin{tabular}{|c|c|c|c|}
\hline Species & $\begin{array}{c}\text { Outer slope } \\
20-35 \mathrm{~m}\end{array}$ & $\begin{array}{l}\text { Fore reef } \\
35-45 \mathrm{~m}\end{array}$ & $\begin{array}{l}\text { Lagoon } \\
20-36 \mathrm{~m}\end{array}$ \\
\hline Stylocoeniella guentheri Bassett-Smith, 1890 & + & + & + \\
\hline Acropora granulosa (Edwards et Haime, 1860) & + & + & + \\
\hline Astreopora myriophthalma (Lamarck, 1816) & + & + & + \\
\hline Montipora composita Crossland, 1952 & + & + & + \\
\hline Pavona varians Verrill, 1864 & + & + & + \\
\hline Leptastrea purpurea (Dana, 1846) & + & + & + \\
\hline Montastrea curta (Dana, 1846) & + & + & + \\
\hline Acanthastrea echinata (Dana, 1846) & + & + & + \\
\hline Psammocora profundacella Gardiner, 1898 & + & + & \\
\hline Pocillopora cf. solida Quelch, 1886 & + & + & \\
\hline Pocillopora verrucosa (Ellis et Solander, 1786) & + & + & \\
\hline Acropora cf. valida (Dana, 1846) & + & + & \\
\hline Montipora verrucosa (Lamarck, 1816) & + & + & \\
\hline Porites australiensis (Vaughan, 1918) & + & + & \\
\hline Cyphastrea serailia (Forskal, 1775) & + & + & \\
\hline Montipora cf. minuta Bernard, 1897 & + & & + \\
\hline Montipora cf. tuberculosa (Lamarck, 1816) & + & & + \\
\hline Leptoseris incrustans (Quelch, 1886) & + & & + \\
\hline Leptoseris mycetoseroides Wells, 1954 & + & & + \\
\hline Pachyseris speciosa (Dana, 1846) & + & & + \\
\hline Pavona maldivensis (Gardiner, 1905) & + & & + \\
\hline Fungia concinna Verrill, 1864 & + & & + \\
\hline Fungia repanda Dana, 1846 & + & & + \\
\hline Herpolitha limax (Esper, 1797) & + & & + \\
\hline Porites lutea Edwards et Haime, 1851 & + & & + \\
\hline Synaraea convexa Verrill, 1864 & + & & + \\
\hline Leptastrea transversa Klunzinger, 1879 & + & & + \\
\hline Acropora exilis (Brook, 1893) & + & & \\
\hline Acropora cf. variabilis (Klunzinger, 1879) & + & & \\
\hline Montipora verrilli Vaughan, 1907 & + & & \\
\hline Gardineroseris planulata (Dana, 1846) & + & & \\
\hline Napopora irregularis Quelch, 1886 & + & & \\
\hline Synaraea irregularis Verrill, 1864 & + & & \\
\hline Favia stelligera (Dana, 1846) & + & & \\
\hline Lobophyllia costata (Dana, 1846) & + & & \\
\hline Psammocora explanulata Horst, 1922 & & & + \\
\hline Psammocora nierstraszi Horst, 1921 & & & + \\
\hline Psammocora cf. obtusangula (Lamarck, 1816) & & & + \\
\hline Montipora erythraea Marenzeller, 1906 & & & + \\
\hline Montipora cf. floweri Wells, 1954 & & & + \\
\hline Montipora spumosa (Lamarck, 1816) & & & + \\
\hline Fungia paumotensis Stutchbury, 1933 & & & + \\
\hline Echinophyllia aspera (Ellis et Solander, 1786) & & & + \\
\hline
\end{tabular}


Table 3. Deep-water coral association of the Wingate Reef off Port Sudan, Red Sea

\begin{tabular}{|c|c|c|c|c|}
\hline \multirow{2}{*}{ Species } & \multicolumn{4}{|c|}{ Outer steep slope } \\
\hline & $20-30 \mathrm{~m}$ & $30-40 \mathrm{~m}$ & $40-50 \mathrm{~m}$ & $50-70 \mathrm{~m}$ \\
\hline Stylophora kuehlmanni Pillai et Scheer, 1982 & + & + & + & + \\
\hline Leptoseris explanata Yabe et Sugiyama, 1941 & + & + & + & + \\
\hline Leptoseris mycetoseroides Wells, 1954 & + & + & + & + \\
\hline Coscinarea monile (Forskal, 1775) & + & + & + & + \\
\hline Alveopora verrilliana Dana, 1872 & + & + & + & + \\
\hline Mycedium elephantotus (Pallas, 1766) & + & + & + & + \\
\hline Psammocora profundacella Gardiner, 1898 & + & + & + & \\
\hline Acropora granulosa (Edwards et Haime, 1860) & + & + & + & \\
\hline Montipora meandrina (Ehrenberg, 1834) & + & + & + & \\
\hline Montipora stilosa (Ehrenberg, 1834) & + & + & + & \\
\hline Pachyseris speciosa (Dana, 1846) & + & + & + & \\
\hline Pavona yabei Pillai et Scheer, 1976 & + & + & + & \\
\hline Fungia fungites (Linné, 1758) & + & + & + & \\
\hline Podabacia crustacea (Pallas, 1766) & + & + & + & \\
\hline Porites echinulata Klunzinger, 1879 & + & + & + & \\
\hline Porites lutea (Edwards et Haime, 1851) & + & + & + & \\
\hline Synaraea undulata Klunzinger, 1879 & + & + & + & \\
\hline Echinopora gemmacea (Lamarck, 1816) & + & + & + & \\
\hline Echinopora lamellosa (Esper, 1795) & + & + & + & \\
\hline Favia pallida (Dana, 1846) & + & + & + & \\
\hline Favites abdita (Ellis et Solander, 1786) & + & + & + & \\
\hline Favites complanata (Ehrenberg, 1834) & + & + & + & \\
\hline Stylophora danae Edwards et Haime, 1850 & + & + & & \\
\hline Stylophora mamillata Pillai et Scheer, 1982 & + & + & & \\
\hline Gardineroseris planulata (Dana, 1846) & + & + & & \\
\hline Leptoseris fragilis Edwards et Haime, 1849 & + & + & & \\
\hline Pavona varians Verrill, 1864 & + & + & & \\
\hline Fungia repanda Dana, 1846 & + & + & & \\
\hline Goniastrea pectinata (Ehrenberg, 1834) & + & + & & \\
\hline Galaxea cf. astreata (Lamarck, 1816) & + & + & & \\
\hline Lobophyllia hemprichi (Ehrenberg, 1834) & + & + & & \\
\hline Dendrophyllia arbuscula Horst, 1922 & + & + & & \\
\hline Stylocoeniella guentheri Bassett-Smith, 1890 & + & & & \\
\hline Psammocora explanulata Horst, 1922 & + & & & \\
\hline Pocillopora damicornis (Linné, 1758) & + & & & \\
\hline Seriatopora hystrix Dana, 1846 & + & & & \\
\hline Leptoseris scabra Vaughan, 1907 & + & & & \\
\hline Pavona cactus (Forskal, 1775) & + & & & \\
\hline Pavona maldivensis (Gardiner, 1905) & + & & & \\
\hline Goniopora tenella (Quelch, 1886) & + & & & \\
\hline Galaxea fascicularis (Linné, 1767) & + & & & \\
\hline Echinophyllia aspera (Ellis et Solander, 1786) & + & & & \\
\hline Psammocora haimeana Edwards et Haime, 1851 & & + & + & \\
\hline Cyphastrea microphthalma (Lamarck, 1816) & & + & + & \\
\hline Favia speciosa (Dana, 1846) & & + & + & \\
\hline Porites solida (Forskal, 1775) & & & + & \\
\hline Favites pentagona (Esper, 1794) & & & + & \\
\hline Astreopora myriophthalma (Lamarck, 1816) & & + & & \\
\hline Favites peresi Faure et Pichon, 1978 & & + & & \\
\hline Leptastrea purpurea (Dana, 1846) & & + & & \\
\hline Platygyra daedalea (Ellis et Solander, 1786) & & + & & \\
\hline Plerogyra sinuosa (Dana, 1846) & & + & & \\
\hline
\end{tabular}


$\mathrm{St}$. Croix, one of the Virgin Islands, is situated $64^{\circ} 50^{\prime} \mathrm{W}$ and $17^{\circ} 45^{\prime} \mathrm{N}$. The island extends over an area of about $15 \times 30 \mathrm{~km}$. Lying southeast of Puerto Rico, the island belongs geologically to the Greater Antilles, geographically to the Lesser Antilles. There are several reefs near the coast. The north-western coast of St. Croix first slopes down to a depth of $10 \mathrm{~m}$ at an angle of 5 to $10^{\circ}$; then at 30 to $40^{\circ}$ to $20 \mathrm{~m}$, and at 70 to $80^{\circ}$ to $50 \mathrm{~m}$. Below that, covered with sponges and Antipatharia, the sea bottom slopes vertically to depths of more than $1000 \mathrm{~m}$. The water is clear with few suspensions. The influence of the Atlantic swell is considerable, and a slight current flows westwards along the coast. The deep-water coral association covers the steep slope between 25 and $50 \mathrm{~m}$ with an abundance of $80 \%$. It consists of the following 13 species: Stephanocoenia michelini, Agaricia agaricites, A. fragilis, A. grahamae, A. lamarcki, A. undata, Siderastrea siderea, Montastrea annularis, $M$. cavernosa, Mycetophyllia alicae, M. danaana, Scolymia lacera, Eusmilia fastigiata. The slope is densely covered with flattened corals, particularly $A$. lamarcki and the disk-shaped ecomorphous $A$. agaricites f. purpurea as well as a number of other Agaricia species (Table 5). Their forms resemble shingles or plates. Montastrea annularis and $M$. cavernosa are mainly crusty, although at $30 \mathrm{~m}$ and below they form thick projecting lips and shingles. Eusmilia fastigiata grows in recesses.

$\mathrm{Cuba}$, the largest island of the Antilles, is surrounded by many coral reefs and island chains (Kühlmann, 1970a, 1974b). Adjacent to several seas, the sublittoral region is exposed to various hydrographic and atmospheric influences, such as different currents, winds and river mouths (Kühlmann, 1970b). Steep walls falling to a depth of more than $300 \mathrm{~m}$ occur sporadically near the shoreline of certain bays. Similar to the St. Croix investigation area, there is, on the west side of the Bay of Matanzas at $80^{\circ} 40^{\prime} \mathrm{W}$ and $23^{\circ} \mathrm{N}$, a fringing reef gradually sloping down from the shore and leading to a steep slope at a depth of $6 \mathrm{~m}$ which, interspersed by a few narrow steps, continues at an angle of 60 to $80^{\circ}$ into the depths (Kühlmann, 1974a). The water is clear, even though the hydrodynamics of this protected location cause a slight and continuous sedimentation, as shown by fine silt layers covering the irregular surface of the steep slope. $60 \%$ of the latter was covered by the following 13 Scleractinia: Stephanocoenia michelini, Madracis formosa, Agaricia agaricites, A. fragilis, Leptoseris cucullata, Siderastrea siderea, Porites astreoides, Colpophyllia natans, Montastrea cavernosa, Meandrina meandrites, Mycetophyllia lamarckiana, Scolymia cubensis, Eusmilia fastigiata and the hydrocoral Stylaster roseus. Below $12 \mathrm{~m}$ the crustaceous shingle- and disk-type forms are so dominant that the slope looks like a deep-water coral association.

\section{DISCUSSION}

Most of the corals belonging to the deep-water associations occur also in shallow waters at depths less than $5 \mathrm{~m}$. The general bathymetric range of the Indopacific species considered here is listed in Table 4; for Caribbean species consult Table 5 as well as the publications of Goreau \& Wells (1967) and Wells (1973). All in all, species of hermatypic corals grow in so broad a depth belt that changes in light intensity and quality, associated with the selective absorption by the waters (Scheer, 1966; Jerlov, 1968, 1970; Kühlmann, 1970b; Jaubert \& Vasseur, 1974), cannot be regarded as the reason for a differentiated depth distribution of most Scleractinia species, as pointed out elsewhere 
(Loya, 1972; Kühlmann, 1980; Dinesen, 1982; Sheppard, 1982). Scatterday (1977) noted that "Many species seem, on the basis of observations made in only one or a few localities, to be in different depths elsewhere".

Dustan (1979) demonstrated for Montastrea annularis that zooxanthellae (Gymnodinium microadriaticum) are in a position to photo-synthesize in a wide range of light intensities and spectral ranges. His findings based on investigations carried out by Goreau \& Wells (1967), explain why individual colonies of this coral species are able to live in depths ranging from 0 to $95 \mathrm{~m}$. Therefore, symbiotic algae of hermatypic corals seem to be adapted to a wide range of light intensities; their optimum, however, is in subdued underwater light. Falkowsky \& Dubinski (1981), investigating transplanted Stylophora pistillata, discovered that shade-adapted individuals are able to adapt to well illuminated habitats after 4 to 8 weeks, perhaps by means of light-dependent changes in the size of the chloroplastids. Wethey \& Porter (1976) suggest, on the basis of experiments with some species of reefbuilding corals, "that given a particular light regime, the algal photosynthetic efficiency, relative to the maximum photosynthetic rate, is independent of the coral species which the algae inhabit". Experiments with ammonia demonstrate that increase of calcification is associated with an elevated rate of photosynthesis (Taylor, 1978). But subsaturation and variation of light are compensated by both endosymbiotic algae and hermatypic corals; presumably the investigated Scleractinia are mainly independent of the particular environmental light conditions (Beyers, 1966; Barnes \& Taylor, 1973; Roth, 1975; Chalker \& Taylor, 1978). For both Acropora cervicornis and Gymnodinium microadriaticum maxima of calcification and photosynthetic capacity occurred at sunrise and sunset, but diminished in constant bright illumination (Chalker, 1977). Ditlev (1978) pointed out that the zooxanthellae of Coeloseris mayeri migrate into deeper tissue layers if exposed to high light intensities. Fricke \& Vareschi (1982) observed special organs in Pleurogyra sinuosa full of zooxanthellae, which can be erected or contracted according to the light conditions of the environment. Lasker (1977. 1981) suggests the existence of two morphs in Montastrea cavernosa: a diurnal one (with greater zooxanthellae densities) and a nocturnal one - perhaps another way of adaptation to different light qualities and quantities. Stiévenart (1975) also pointed out that there are two different ecological populations, one at a depth of $9 \mathrm{~m}$, the other at a depth of $30 \mathrm{~m}$. Not all processes of light adaptations by hermatypic corals and, in particular, by their zooxanthellae are clear, and some of the relevant investigations came to conflicting conclusions (Chalker \& Taylor, 1975).

According to Stiévenart $(1975 a, b)$ average amounts of symbiotic algae and the ratio of chlorophyll c / chlorophyll a in Mycetophyllia lamarckiana decrease as depth increases. In contrast, Zvalinsky et al. (1978) found in "Acropora" from shallow waters, caves and from depths of $30-40 \mathrm{~m}$ that, parallel with decreasing light intensities, the number of zooxanthellae and simultaneously the content of photosynthetic pigments increase.

All results presented here lead to the assertion that hermatypic coral species are generally light-dependent because of their symbiosis with zooxanthellae, but most of them can compensate in a different manner for the daily and local variations in the quantity of light, even at greater depths, although metabolism and growth rates vary according to the degree of deviation from the optimum (Strömgren, 1976; Barnes \& Crossland, 1978). Consequently, differing degrees of turbidity reduce or extend the 


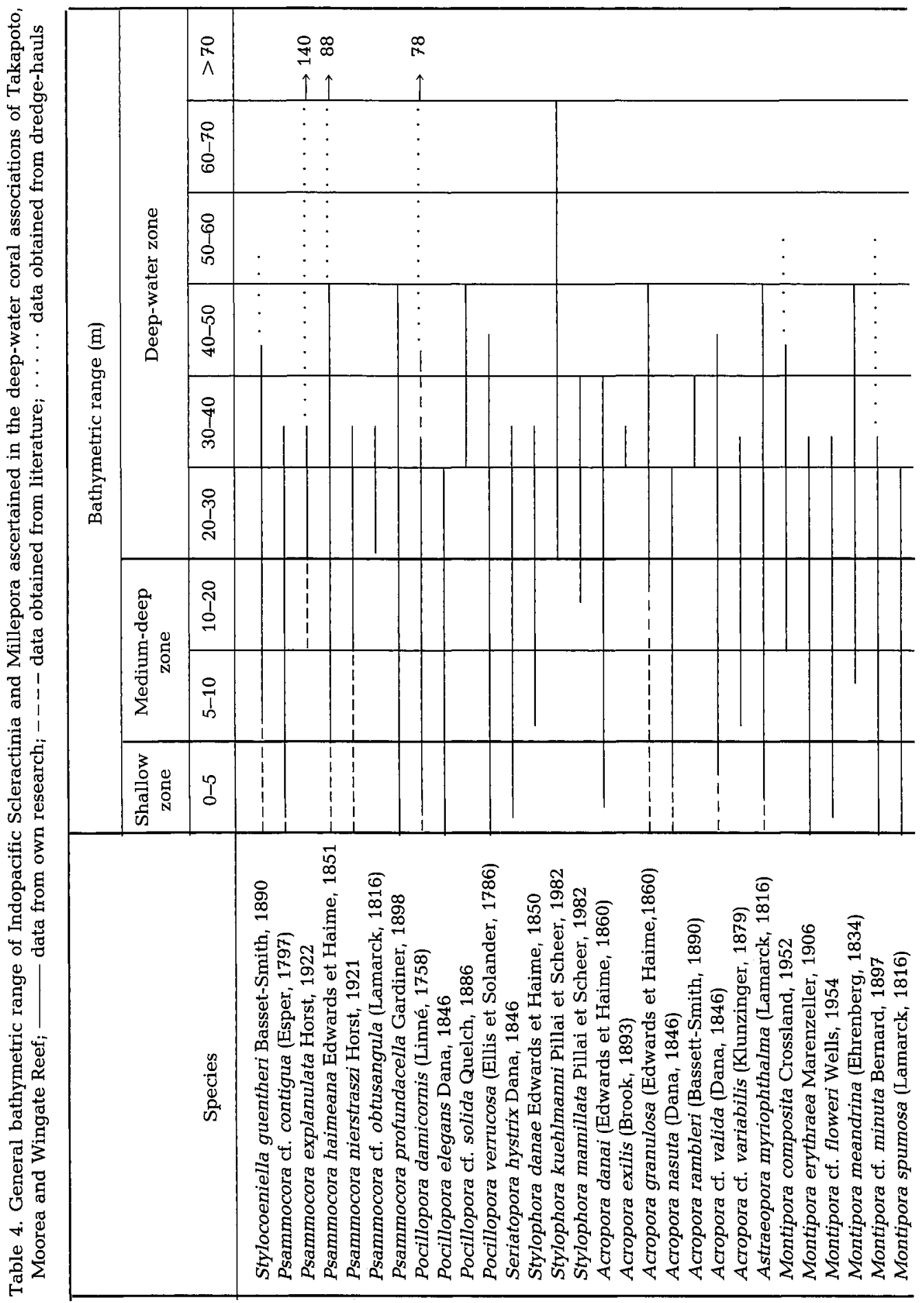




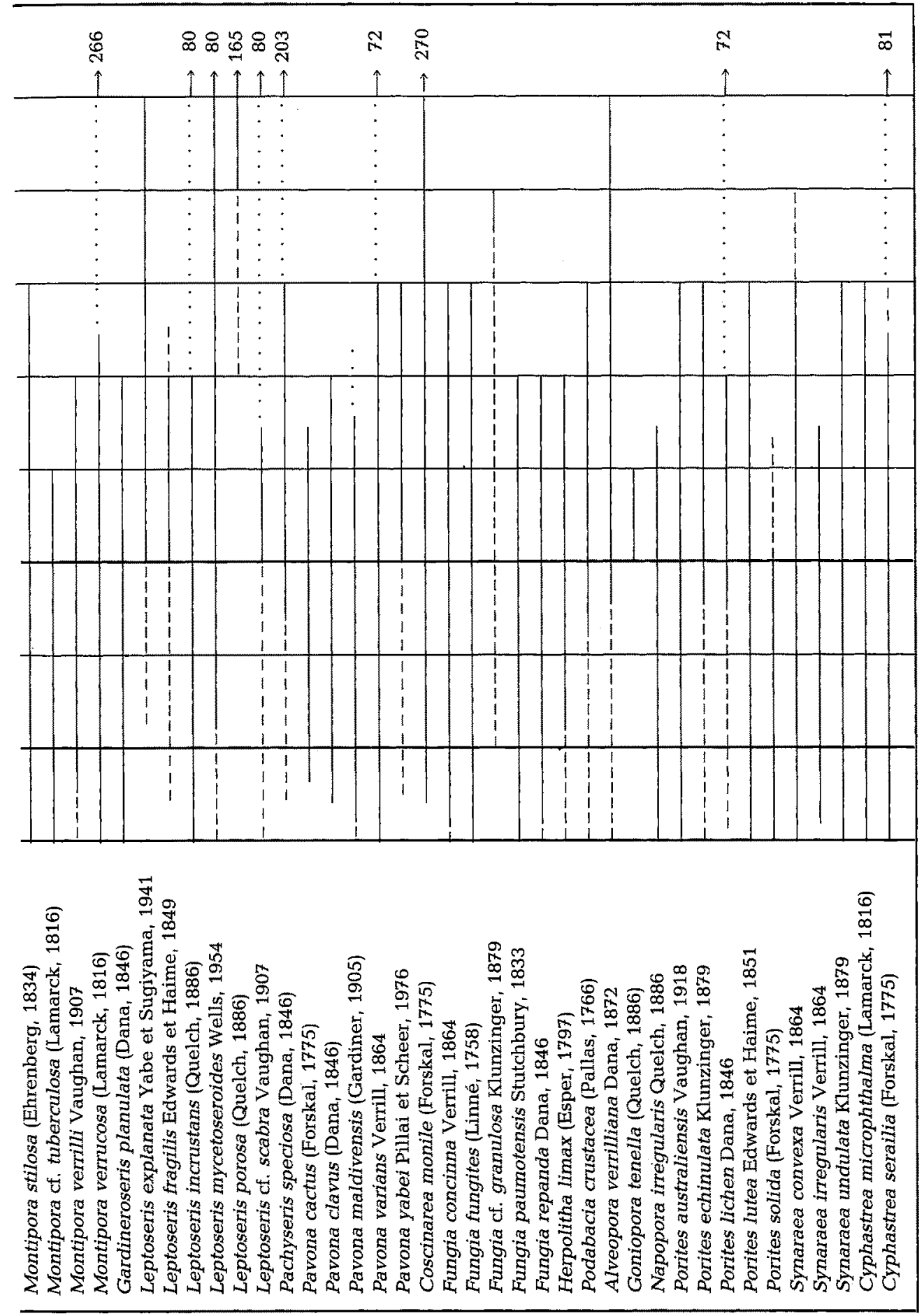




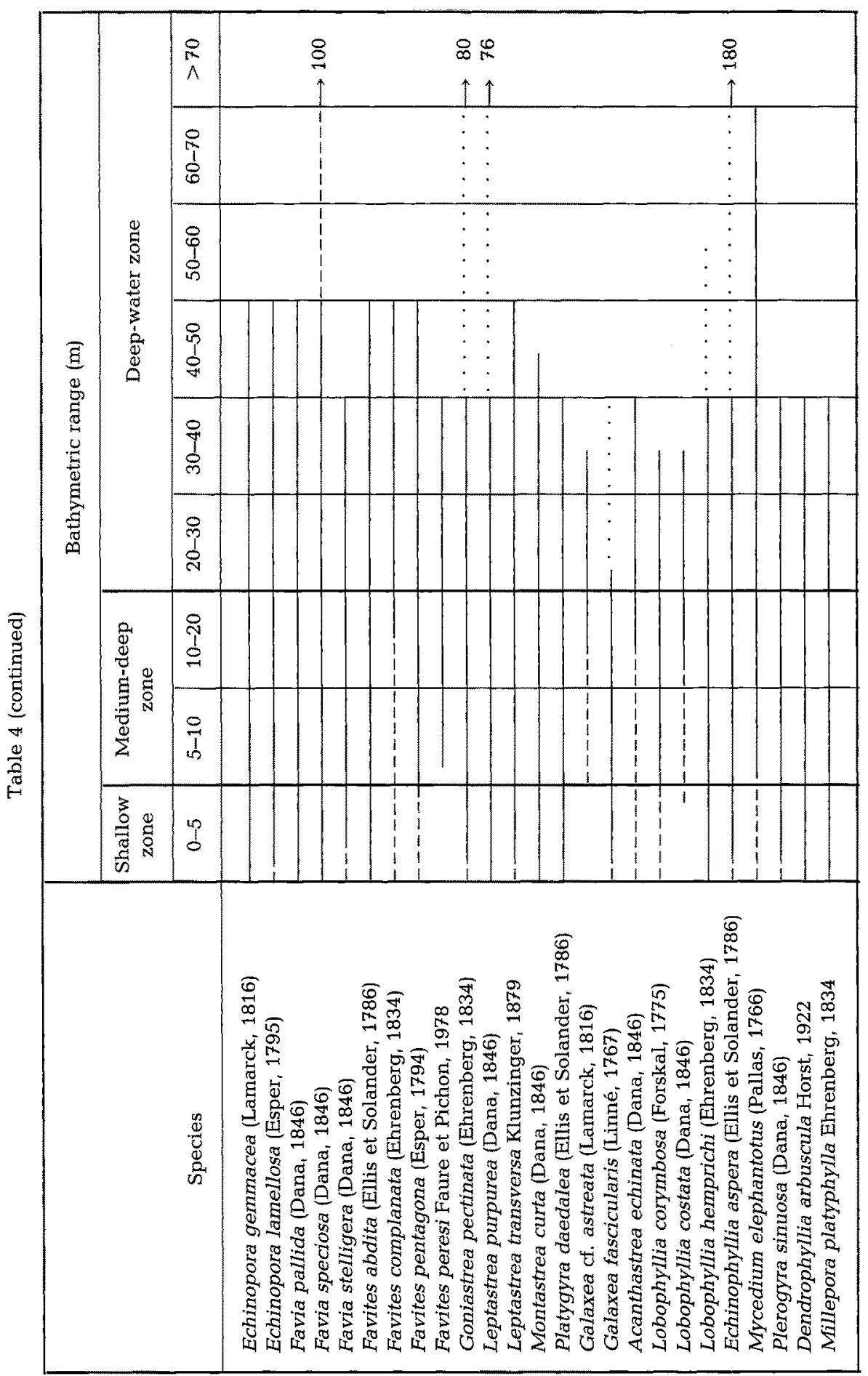


Deep-water coral associations

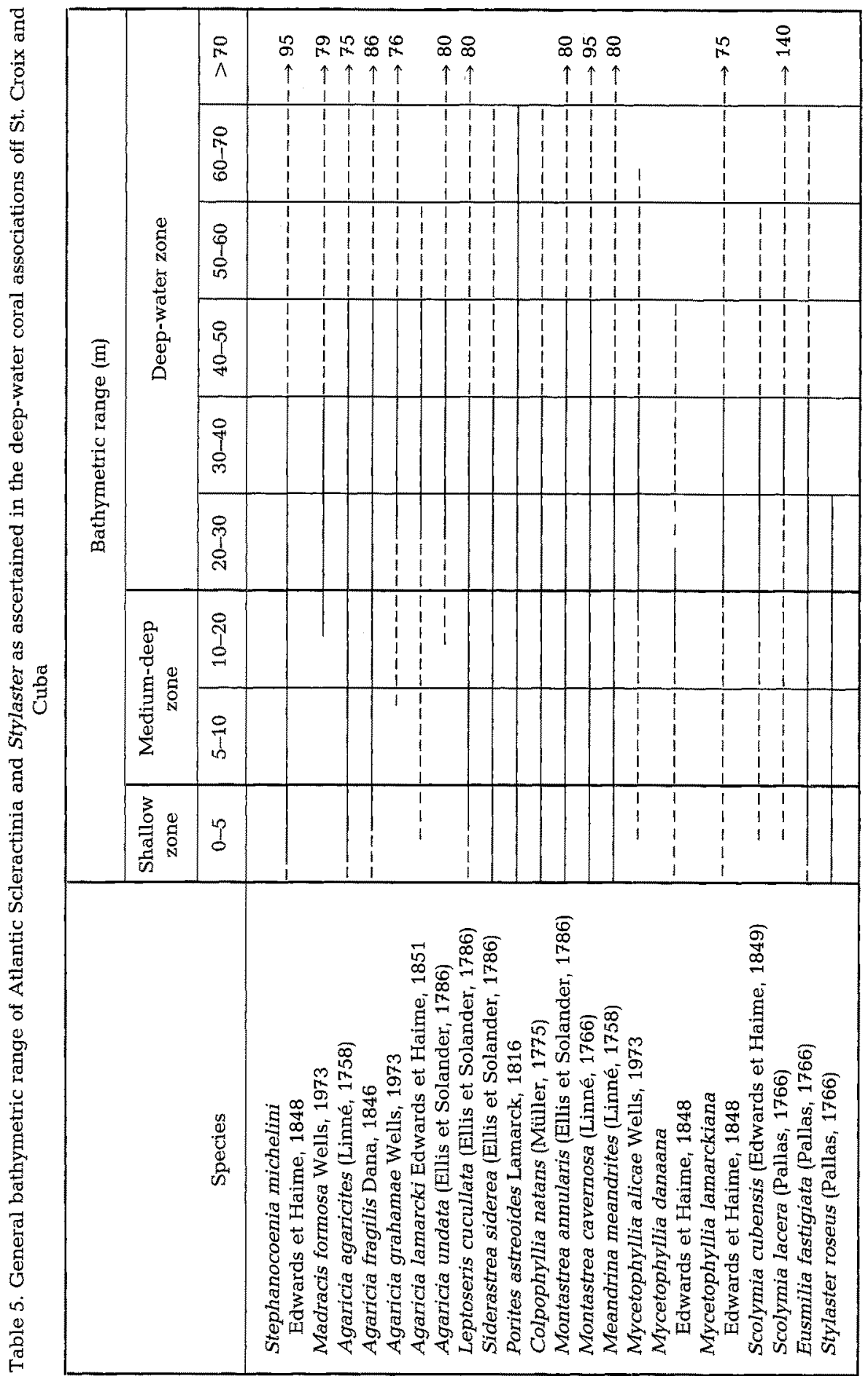


average depth distributional belt of hermatypic corals as a whole, but do not influence the depth occurrence of the individual coral species.

This is corroborated by the occurrence of the Agariciidae deep-water association below $12 \mathrm{~m}$ at Matanzas, while it occurs below $25 \mathrm{~m}$ off St. Croix. The water is clear and well illuminated in both habitats, but the site of the Bay of Matanzas is very much more protected (Kühlmann, 1974a); thus, water movement is just as reduced here at a depth of $12 \mathrm{~m}$ as off St. Croix at $25 \mathrm{~m}$. Nor can light be held responsible for the varying bathymetric occurence of Caribbean deep-water coral associations; it is more likely that different hydrodynamic conditions and other controlling factors exert the decisive influence (Kühlmann, 1971).

Individual species have the same pattern of behaviour: Napopora irregularis is not rare at a depth of $10 \mathrm{~m}$ on the outer slopes of Moorea, while in particularly clear and agitated waters it is dominant at depths between 25 and $35 \mathrm{~m}$. Yet this species is also found in shallow lagoons at a depth of $1 \mathrm{~m}$, if clear water is continuously driven over the reef edge and strongly agitated by the tradewind. The example shows clearly that the species is independent of a certain light quality and quantity. It is important to keep in mind that there is an equal occurrence of most coral species in deep and shallow waters (Tables 4,5 ), if hydrodynamical conditions, substrate and sedimentation are comparable (Kühlmann, 1977, 1980).

The situation is somewhat different as regards the Takapoto deepwater coral associations, which differ greatly in terms of species composition. The outer slope on the windward side is dominated by large Porites australiensis and Synaraea convexa and Leptoseris incrustans, while Platygyra daedalea and Lobophyllia corymbosa are predominant on the steep slopes situated in the depths of the lagoon. Although the latter occur under the influence of a stronger sedimentation in more turbid water and the effects of lack of light cannot therefore be excluded, the outer slopes on the windward and leeward sides still have the same clear water with optimum light conditions. Accordingly, this is another case where light is not a factor affecting the depth of coral species. The deep-water coral associations, nonetheless typified by varying dominant species, are dependent on the hydrodynamic conditions which differ greatly in the two habitats. The windward shore is under the strong influence of the tradewind, but the leeward shore is sheltered.

Hence the term "deep-water corals" must not be associated with the light factor, and changes in light intensity do not result necessarily in changes of species composition, as has been suggested in the past (Jaubert \& Vasseur, 1973; Mergner \& Scheer, 1974), because most species live in both shallow and deep waters. On the noxious effects of UV radiation Siebeck (1981) concluded: "Considering the highly vertical UV gradients due to the exponential drop in radiation, it is obvious that ultraviolet light is important not only for the presence or absence of the various species of organisms, but also for their vertical distribution within the upper reef region, in that portion influenced by UV light." Simultaneously, he observed Turbinaria mesenterina colonies at a depth of 5-6 m to be more sensitive to UV radiation than those occurring at a depth of 1-2 $\mathrm{m}$. Jokiel \& York (1982) found that Pocillopora damicornis treated with UV-light during the growth phase contained a greater concentration of the "S-320" UV-absorbing substances than corals living in filtered sunlight, lacking solar ultraviolet. This species is capable of adapting to various intensities of UV light and of existing in different depths. Mucus is 
secreted plentifully by the stony corals if they are in extremely shallow water or when taken out of the water for examination. This mechanism, besides being a safeguard against desiccation, is also a safeguard against UV damage. It is possible that the symbiotic zooxanthellae also operate as a protective factor against UV radiation, since hermatypic corals generally grow on fully exposed, insolated substratum without any damage. On the other hand, hermatypic but aposymbiotic corals, such as Dendrophyllia arbuscula, Tubastrea cf. coccinea and Phyllangia pallida in the Red Sea and Tubastrea coccinea, Astrangia solitaria and Phyllangia americana in the Caribbean region settle only in dark shady places of the reefs because of lacking symbiotic algae. Thus, UV radiation is not responsible for the vertical distribution of several hermatypic symbiotic scleractinians. The term "deep-water coral" should be determined more precisely, whereby the findings made so far relate solely to the status of the species considered and not to the ecological growth forms of hermatypic corals.

Flattened growth - considered to be typical of many of the coral colonies growing in deep water (Kawaguti, 1937; Goreau, 1963; Barnes, 1973; Faure, 1974; Bonem \& Stanley, 1977; Meischner \& Meischner, 1977) - is perhaps light-dependent, unlike depth occurrence of the species involved. This is particularly evident in stony coral species which form massive colonies in shallow or medium-deep waters, becoming increasingly flatter in deeper waters. Goreau (1959) and Dustan (1979) ascribed this phenomenon to a reduction in the output of calcium carbonate because of a lower photosynthetic rate. Since the spherical form has the largest volume with a small surface, the flattened form can be considered an expression of the economy of skeleton material. That is why coral species occurring as massive colonies in shallow waters, such as Porites lutea, Montastrea annularis, Echinopora lamellosa, Favia speciosa and others, form flattened lips and overlapping shingles at greater depths. On the other hand, the soft leaf and diskshaped colonies, which offer the water large surfaces to act on, would be immediately destroyed in shallow or medium-deep water. Favia stelligera colonies, which are column-shaped in shallow waters, are flat at greater depths. Shrublike forms such as Acropora granulosa, A. danai and A. rambleri are characterized by flattened branches in deeper waters. The most numerous species in deep-water regions are those which grow solely or predominantly in the shape of a disk: they include Leptoseris incrustans, $L$. mycetoseroides, Pachyseris speciosa, Podabacia crustacea, Coscinarea monile and others.

Even the orientation on the substrate of these coral colonies is characteristic. Crustaceous colonies such as some Montipora and Psammocora species and Stylophora mamillata follow the relief of the substrate. Even large, disk-shaped corals such as Agaricia, Leptoseris, Podabacia and Pachyseris are orientated vertically. Small disk or leaf-shaped colonies such as Agaricia lamarcki and Synaraea species may also be horizontally oriented. Scleractinia, such as Favia, Favites, Montastrea and Porites species, which are flattened in deep water while otherwise being massive, have a horizontal or, particularly the large colonies, a downwards-inclined active surface. Branching species, such as Acropora, Madracis and Stylophora kuehlmanni, also grow horizontally. Only St. kuehlmanni displays branches directed upwards even in deepwater regions, provided that it grows on a horizontal rocky bottom.

As a result of investigations on flat slopes in the medium-depth range, Loya (1972) pointed out that, as a rule, the size of the colonies decreases as depth increases. 
However, in the deep-water range of the steep slopes investigated, between 20 and $40 \mathrm{~m}$, large colonies predominate. The disks, plates and lips formed by Agaricia agaricites f. purpurea, Leptoseris cucullata, Porites australiensis and Leptoseris incrustans often have a diameter exceeding $1 \mathrm{~m}$, while the diameter of Agaricia undata, Podabacia crustacea, Pachyseris speciosa and Leptoseris mycetoseroides may be more than $0,5 \mathrm{~m}$. Such gigantism of the colonies must probably be attributed to the greatly subdued hydrodynamic conditions. While coral colonies in shallow waters are broken down relatively frequently by high, rough waves, as demonstrated by the huge dams and dunes of debris on the shores (Kühlmann, 1970a, 1980), coral colonies in deep-water zones are usually not subjected to violent water movement. While corals in shallow waters have to resettle again and again and, apart from particularly robust Poritidae, Faviidae and some others, are able to form only small or medium-sized colonies resulting from the destructive action of storms, the deep-water-zone corals have plenty of time to form large and broad colonies even at slow growth rates. In short, deep-water coral associations existing between depths of 20 and $50 \mathrm{~m}$ are mainly flattened, large, obliquely or vertically orientated growth forms of hermatypic symbiotic Scleractinia. The frequent deep-water growth forms are, together with the few species growing solely in deep water, designated by the ecological term "deep-water corals" which should in no way be confused with the ahermatypic "deep-sea corals" living in the aphotic zone.

Below 40 to $50 \mathrm{~m}$, a decrease in size of the colonies is accompanied by a distinct decrease of coral growth. It can be concluded that the optimum deep-water zone is between 20 and $50 \mathrm{~m}$, provided there are favourable turbidity and light conditions. As has been shown by the example of the Takapoto Atoll, a differentiation of coral

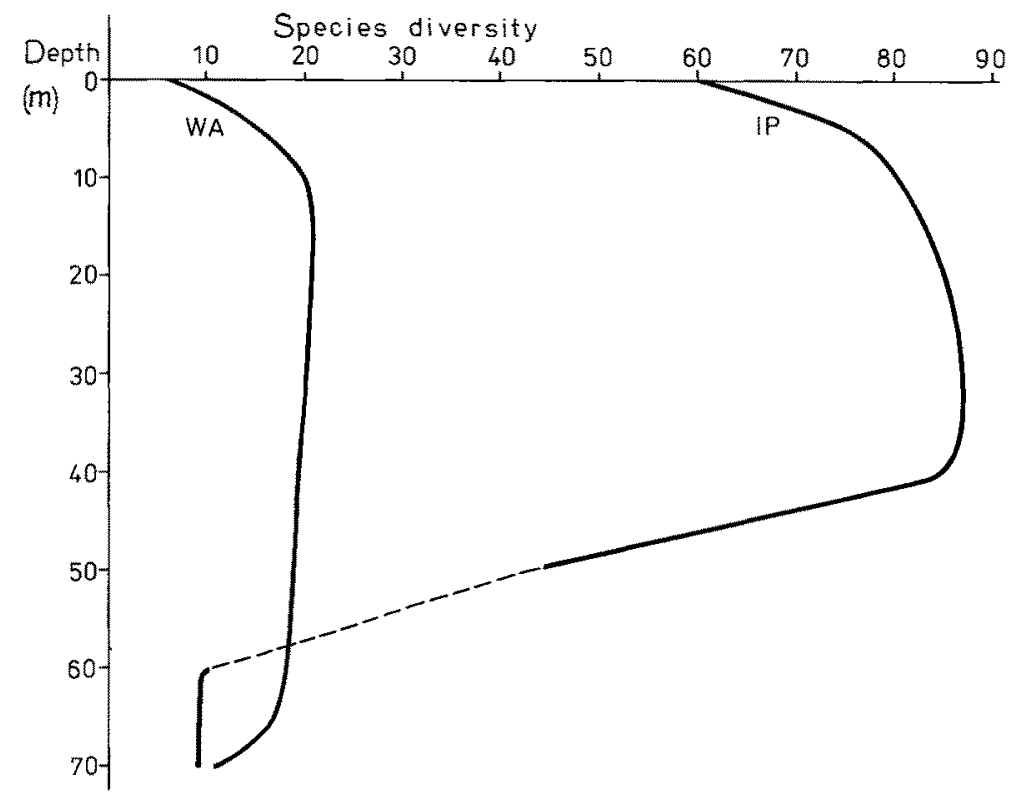

Fig. 3. Species diversity (number of species) of stony corals at different water depths in the West Atlantic (WA) and Indopacific Ocean (IP) 
associations can occur despite equally balanced environmental conditions in the deepwater zone of the same reef, if there are different hydrodynamic conditions.

Steep, hard bottom substrates are particularly characteristic of the deep-water zone of coral reefs. Flat rocky substrates sand up quickly through sediment settling in calm water. Waterborme sediments were not permanent on the steep substrates on which these investigations were conducted because even slight water movement could easily stir them up and transport them to lower depths. When sediments are lacking, the water is rarely turbid in the vicinity of steep slopes and this is particularly favourable for coral growth. Moreover, the water is subjected to continuous exchange processes brought about by the slow currents usually occurring there. Thus, the following conclusion is drawn: steep slopes with an angle of inclination between 50 and $80^{\circ}$ and at depths between 20 and $50 \mathrm{~m}$ are particularly suited for colonization by deep-water coral associations. The interaction and alteration of the environmental factors of hydrodynamics, substrate and sedimentation constitute a complex of mechanical factors acting in concert. It appears to be responsible for the formation of coral associations (Kühlmann, 1977) together with other controlling factors such as competition (Lang, 1971, 1973; Hildeman et al., 1975; Sheppard, 1982), conditions of settlement (Sammarco et al., 1974), predators (Salvini-Plawen, 1972; Collins, 1974, 1975; Harris, 1975; Frydl, 1979; Lauckner, 1980), population dynamics (Margalef, 1978) and others. Typical deep-water coral associations occurring in more shallow waters are exceptions due to altered conditions of mechanical factors. Coral growth appears to be impeded below 40 to $50 \mathrm{~m}$ because of cooler temperature, stronger sedimentation in calm water and greatly reduced light intensities. It is reduced in overhanging substrates because corals projecting too far into the water or becoming too heavy break off and fall into deeper zones.

Of the 92 coral species (one hydrocoral) in the Central Pacific and the Red Sea living below $20 \mathrm{~m}$ (Table 4), 74 of them occur above $5 \mathrm{~m}$ and 12 of them at depths between $5 \mathrm{~m}$ and $20 \mathrm{~m}$ (Fig. 3). Only 6 Scleractinia species were found exclusively below $20 \mathrm{~m}$. Although this calculation is still based on incomplete data, as many as $80 \%$ belong to species which exist in shallow as well as in medium-deep and deep-water zones of the reefs; $13 \%$ occur in both medium-deep and deep-water ranges and a mere $7 \%$ are found exclusively in deep-water zones. Of the 21 coral species (among them 1 hydrozoan) found in the Western Atlantic, in the deep water of the reefs of St. Croix and Cuba (Table 5), Goreau \& Wells (1967), Wells (1973) and Zlatarski \& Estalella (1982) attributed 18 species to shallow waters less than $5 \mathrm{~m}$ deep and 3 species to the medium-deep zone between $5 \mathrm{~m}$ and $20 \mathrm{~m}$. Solely Mycetophyllia reesi has been found so far at depths between 27 and $76 \mathrm{~m}$. Accordingly, $85 \%$ of the corals are found in the deep-water zone and $14 \%$ in the medium-deep zone, while less than $1 \%$ live in the deep-water zone only (Fig. 3). Thus, depth zoning of hermatypic symbiotic coral species, growing between shallow water $(<5 \mathrm{~m})$ and deep water $(>20 \mathrm{~m})$ is not in conformity with the spectrum of light selectively absorbed by the water, but rather with hydrodynamics (Graus et al., 1977), sedimentation, surface condition, substrate inclination and other factors which change with increasing depth. The occurrence of some hermatypic corals exclusively in the deep-water zone may be attributed to mechanical conditions, light, other ecological factors and/or the genetically fixed property of forming only fragile skeletons. 
Acknowledgements. For support in the aforementioned investigations, I extend my sincere thanks to the Ministry of Higher and Technical Education of the German Democratic Republic, to the Humboldt University, the Havana (Cuba) Instituto de Oceanologia, the University of Havana, the St. Croix West Indies Laboratory, especially R. Dill, to the Antenne de Musée de la Histoire Naturelle de Paris in Moorea, especially B. Salvat and G. Vergonzanne, and to the VE Kombinat Seereedere und Hafenwirtschaft Rostock, especially the crew of the MS "Georg Schumann". I wish to thank J.-P. Chevalier (Paris), C. S. G. Pillai (Cochin), G. Scheer (Darmstadt) and M. Wijsman-Best (Leiden) for their extensive aid in taxonomic determinations. I dedicate this paper to my friend, Dr. Jean-Pierre Chevalier who died suddenly in April 1981, in the middle of his work in the Pacific with sincere affection and in deep respect.

\section{LITERATURE CITED}

Bak, R. P. M., 1977. Coral reefs and their zonation in Netherlands Antilles. - Stud. Geol., Tulsa 4, 3-16.

Barnes, D. J., 1973. Growth in colonial scleractinians. - Bull. mar. Sci. 23, 280-298.

Barnes, D. J. \& Crossland, C. J., 1978. Diurnal productivity and apparent ${ }^{14}$ C-calcification in the staghorn coral, Acropora acuminata.-Comp. Biochem. Physiol. 59A, 133-138.

Barnes, D. J. \& Taylor, D. L., 1973. In situ studies of calcification and photosynthetic carbon fixation in the coral Montastrea annularis. - Helgoländer wiss. Meeresunters. 24, 284-291.

Beyers, R. J., 1966. Metabolic similarities between symbiotic coelenterates and aquatic ecosystems. - Arch. Hydrobiol. 62, 273-284.

Bonem, R. M. \& Stanley, G. D., 1977. Zonation of a lagoonal patch reef: analysis, comparison, and implications for fossil bioherms assemblages. - Proc. 3rd int. Coral Reef Symp., Miami, 2, 175-181.

Caspers, H., 1968. Biology of a hypersaline lagoon in a tropical atoll island (Laysan). - Proc. Symp. recent Adv, trop. Ecol., Varanasi, 3, 326-333.

Caspers, H., 1981. On the ecology of hypersaline lagoons on Laysan Atoll and Kauai Island, Hawaii, with special reference to the Laysan duck, Anas laysanensis Rothschild. - Hydrobiologia 82, 261-270.

Chalker, B. E., 1977. Daily variation in the calcification capacity of Acropora cervicornis. - Proc. 3rd int. Coral Reef Symp., Miami, 2, 417-423.

Chalker, B. E. \& Taylor, D. L., 1975. Light-enhanced calcification, and the role of oxidative phosphorylation in the coral Acropora cervicomis. - Proc. R. Soc. (B) 190, 323-331.

Chalker, B. E. \& Taylor, D. L., 1978. Rhythmic variations in calcification and photosynthesis associated with the coral Acropora cervicornis (Lamarck). - Proc. R. Soc. (B) 201, 179-189.

Chevalier, J.-P., 1971. Les scléractiniaires de la Mélanésie française (Nouvelle-Calédonie, lles Chesterfield, lles Loyauté, Nouvelles-Hébrides). Brill, Leiden, $1,1-307$.

Chevalier, J.-P., 1973. Geomorphology and geology of coral reefs in French Polynesia. In: Biology and geology of coral reefs. Ed. by O. A. Jones \& R. Endean. Acad. Pr, New York, 1, 113-141.

Chevalier, J.-P., 1975. Les scléractimiaires de la Mélanésie française (Nouvelle-Calédonie, Iles Chesterfield, Iles Loyauté, Nouvelles-Hébrides). Singer Polignac, Paris, 2, 1-407.

Chevalier, J.-P., 1977. Origin of the reef formations of Moorea Island (Archipelago of la Société). Proc. 3rd. int. Coral Reef Symp., Miami, 2, 283-287.

Collins, A. R. S., 1974. Biochemical investigation of two responses involved in the feeding behaviour of Acanthaster planci (L.). I. Assay methods and preliminary results. - J. exp. mar. Biol. Ecol. 15, 173-184.

Collins, A. R. S., 1975. Biochemical investigation of two responses involved in the feeding behaviour of Acanthaster planci (L.). II. Isolation and characterization of chemical stimuli. - J. exp. mar. Biol. Ecol. 17, 69-86.

Crossland, C., 1952. Madreporaria, Hydrocorallinae, Heliopora and Tubipora. - Scient. Rep. Gt Barrier Reef Exped. 6, 85-257.

Dinesen, Z. D., 1980. A revision of the coral genus Leptoseris (Scleractinia: Fungiina: Agariciidae). - Mem. Qd Mus. 20, 181-235.

Dinesen, Z. D., 1982. Regional variation in shade-dwelling coral assemblages of the Great Barrier Reef Province. - Mar. Ecol. Prog. Ser. 7, 117-123. 
Ditlev, H., 1978. Zonation of corals (Scleractinia: Coelenterata) on intertidal reef flats at Ko Phuket, Eastern Indian Ocean. - Mar. Biol. 47, 29-39.

Duerden, J. E., 1902. West Indian madreporarian polyps. - Mem, natn. Acad. Sci. 8, 399-648.

Dustan, P., 1979. Distribution of zooxanthellae and photosynthetic chloroplast pigments of the reefbuilding coral Montastrea annularis Ellis and Solander in relation to depth on a West Indian coral reef. - Bull. mar. Sci. 29,79-95.

Falkowsky, P. G. \& Dubinski, Z., 1981. Light-shade adaptation of Stylophora pistillata, a hermatypic coral from the Gulf of Eilat. - Nature, Lond. 289, 172-174.

Faure, G., 1974. Morphology and biology of the coral reef discontinuities in Rodriguez Island (Mascarene Archipelago, Indian Ocean). - Proc. 2nd int. Coral Reef Symp., Brisbane, 2, 161-172.

Faure, G. \& Pichon, M., 1978. Description de Favites peresi, nouvelle espèce de Scleractiniaire hermatypique de l' océan Indien (Cnidaria, Anthozoa, Scleractinia). - Bull. Mus. natn. Hist. nat., Paris (Sér. 3, Zool.) 352, 107-127.

Fricke, H. \& Vareschi, E., 1982. A scleractinian coral (Plerogyra sinuosa) with "photosynthetic organs". - Mar. Ecol. Prog. Ser. 7, 273-278.

Frydl, P., 1979. The effect of parrotfish (Scaridae) on coral in Barbados, W. I. - Int. Revue ges. Hydrobiol. 64, 737-748.

Gardiner, J. S., 1898. On the perforate corals collected by the author in the South Pacific. - Proc. zool. Soc. Lond. 1898 (17), 257-276.

Gardiner, J. S, 1898. On the fungid corals collected by the author in the South Pacific. - Proc. zool. Soc. Lond. 1898 (35), 525-539.

Gardiner, J. S., 1898. On the turbinolid and oculinoid corals collected by the author in the South Pacific. - Proc. zool. Soc. Lond. 1898 (65), 994-1000.

Gardiner, J. S., 1904. Madreporaria, Pts. I and II. In: The fauna and geography of the Maldive and Laccadive Archipelagoes. Ed. by J. S. Gardiner. Univ. Pr., Cambridge, 2, (3), 755-790.

Gardiner, J. S., 1905. Madreporaria, Pts. III and IV. In: The fauna and geography of the Maldive and Laccadive Archipelagoes. Ed. by J. S. Gardiner. Univ. Pr., Cambridge, 2 (Suppl. 1), 933-957.

Goreau, T. F., 1959. The ecology of Jamaican coral reefs. I. Species composition and zonation. Ecology 40,67-90.

Goreau, T. F., 1963. Calcium carbonate deposition by coralline algae and hermatypic corals in relation to their roles as reef builders. - Ann N. Y. Acad. Sci. 109, 127-167.

Goreau, T. F. \& Goreau, N. I, 1973. The ecology of Jamaican coral reefs. II. Geomorphology, zonation, and sedimentary phases. - Bull. mar. Sci. 23, 399-464.

Goreau, T. F. \& Land, L. S., 1974 . Fore-reef morphology and depositional processes, North Jamaica. - Spec. Publs. Soc. econ. Palaeont. Miner., Tulsa 18,77-89.

Goreau, T. F. \& Wells, J. W., 1967. The shallow-water Scleractinia of Jamaica: Revised list of species and their vertical distribution range. - Bull. mar. Sci. 17, 442-453.

Graus, R. R. Chamberlain, J. A. \& Boker, A. M., 1977. Structural modification of corals in relation to waves and currents. In: Reefs and related carbonates - ecology and sedimentology. Ed. by S. H. Frost, M. P. Weiss \& J. B. Saunders. Am. Ass. Petr. Geol., Tulsa, 135-153.

Harris, L. G., 1975. Studies on the life history of two coral-eating nudibranchs of the genus $P$ hestilla. - Biol. Bull. mar. biol. Lab., Woods Hole 149, 539-550.

Hildeman, W. H., Linthicum, D. S. \& Vann, D. C., 1975. Transplantation and immunoincompatibility reactions among reef-building corals. - Immunogenetics 2, 269-284.

Hoffmeister, J. W., 1925. Some corals from American Samoa and the Fiji islands. - Pap. Dep. mar. Biol. Carnegie Instn Wash. 22, 1-90.

Horst, C. J. van der, 1922. The Madreporaria of the Siboga Expedition, Pt. III, Eupsammidae. Siboga Exped. 16c, 47-75.

Jaubert, J. M. \& Vasseur, P., 1973. Essai d’ interprétation de la répartition de certains peuplements sciaphiles du Grand Récif de Tuléar (Madagascar) à partir d' enregistrements des variations de 1' éclairement. - C. r. hebd. Séanc. Acad. Sci., Paris 276, 2059-2062.

Jaubert, J. M. \& Vasseur, P., 1974. Light measurements: duration aspect and the distribution of benthic organisms in an Indian Ocean coral reef (Tulear, Madagascar). - Proc. 2nd int. Coral Reef Symp., Brisbane, 2, 127-142.

Jerlov, N. G., 1968. Optical oceanography. Elsevier, Amsterdam, 194 pp. 
Jerlov, N. G., 1970. Light, general introduction. In: Marine ecology. Ed. by O. Kinne. Wiley, London, $1(1), 95-102$.

Jokiel, P. L. \& York, R. H. jr., 1982. Solar ultraviolet photo-biology of the reef coral Pocillopora damicornis and symbiotic zooxanthellae. - Bull. mar. Sci. 32, 301-315.

Kawaguti, S., 1937. On the physiology of reef corals. II. The effect of light on colour and form of reef corals. - Palao trop. biol. Stn Stud. 2, 199-208.

Klunzinger, C. B., 1879. Die Korallthiere des Rothen Meeres. 2. Theil, Steinkorallen, 1. Abschnitt. Madreporaceen und Oculinaceen. Gutmann, Berlin, $88 \mathrm{pp.}$

Kühlmann, D. H. H., 1970a. Die Korallenriffe Kubas. I. Genese and Evolution. - Int. Revue ges. Hydrobiol. 55, 729-756.

Kühlmann, D. H. H., 1970b. Studien über physikalische und chemische Faktoren in kubanischen Riffgebieten. - Acta hydrophys. 15, 105-152.

Kühlmann, D. H. H., 1971. Die Korallenriffe Kubas. II. Zur Ökologie der Bankriffe und ihrer Korallen. - Int. Revue ges. Hydrobiol. 56, 145-199.

Kühlmann, D. H. H., 1974a. Die Korallenriffe Kubas. III. Riegelriff und Korallenterrasse, zwei verwandte Erscheinungen des Bankriffs. - Int. Revue ges. Hydrobiol. 59, 305-325.

Kühlmann, D. H. H., 1974b. The coral reefs of Cuba. - Proc. 2nd int. Coral Reef Symp., Brisbane, 2, 69-83.

Kühlmann, D. H. H., 1977. Coral reefs - their importance and imperilment. - UNESCO/UNEP int. post-graduate training course on ecosystem management at the Techn. Univ. Dresden, $5(4)$, $58-63$.

Kühlmann, D. H. H., 1980. Coral associations and their value for paleontological research. - Acta palaeont. pol. $25,459-466$.

Lang, J. C., 1971. Interspecific aggression by scleractinian corals. 1. The rediscovery of Scolymia cubensis (Milne Edwards \& Haime). - Bull. mar. Sci. 21, 952-959.

Lang, J. C., 1973. Interspecific aggression by scleractinian corals. 2 . Why the race is not only to the swift. - Bull. mar. Sci. 23, 260-279.

Lasker, H. R., 1977. Patterns of zooxanthellae distribution and polyp expansion in the reef coral Montastrea cavernosa. - Proc. 3rd int. Coral Reef Symp., Miami, 1, 607-613.

Lasker, H. R., 1981. Phenotypic variation in the coral Montastrea cavernosa and its effects on colony energetics. - Biol. Bull. mar. biol. Lab., Woods Hole 160, 292-302.

Lauckner, G., 1980. Diseases of Cnidaria. In: Diseases of marine animals. Ed. by O. Kinne. Wiley, Chichester, 1, 169-237.

Loya, Y., 1972. Community structure and species diversity of hermatypic corals at Eilat, Red Sea. Mar. Biol. 13, 100-123.

Margalef, R., 1978. General concepts of population dynamics and food links. In: Marine ecology. Ed. by O. Kinne. Wiley, Chichester, 4, 617-704.

Matthai, G., 1924. Report on the madreporarian corals in the collection of the Indian Museum, Pt. 1. - Mem. Indian Mus. 8, 1-59.

Mayer, A. G., 1918. Ecology of the Murray Island coral reef. - Pap. Dep. mar. Biol. Carnegie Instn Wash. 9, 1-48.

Meischner, D. \& Meischner, U., 1977. Bermuda south shore reef morphology. - Proc. 3rd int. Coral Reef Symp., Miami, 2, 243-250.

Mergner, H. \& Scheer, G., 1974. The physiographic zonation and the ecological conditions of some South Indian and Ceylon coral reefs. - Proc. 2nd int. Coral Reef Symp., Brisbane, 2, 31-53.

Pichon, M., 1972. The coral reefs of Madagascar. In: Biogeography and ecology in Madagascar. Ed. by R. Battistini \& G. Richard-Vindard. Junk, The Hague, 367-410.

Pichon, M., 1977. Recent studies on the reef corals of the Philippine Islands and their zoogeography. - Proc. 3rd int. Coral Reef Symp., Miami, 1, 149-154.

Pillai C. S. G. \& Scheer, G., 1976. Report on the stony corals from the Maldive Archipelago. Zoologica, Stuttg. 126, 1-83.

Quelch, J. H., 1886. Report on the reef-corals collected by H. M. S. Challenger during the years 1873-76. - Rep. scient. Results Voyage HMS Challenger (Zool.) 45, 1-203.

Roos, P. J., 1964. The distribution of reef corals in Curaçao. - Stud. Fauna Curaçao 20, 1-51.

Rosen, B. R., 1978. Nature and significance of microatolls, - Phil. Trans. R. Soc. (B) 284, 115-122. 
Roth, A. A., 1975. Some effects of light on calcification in corals. - Abstr. Symp. Contr. Pap., Meeting West. Soc. Nat, San Francisco, 56, 29.

Salvini-Plawen, L. v., 1972. Cnidaria as food-sources for marine invertebrates. - Cah. Biol. mar. 13, $385-400$.

Sammarco, P. W., Levinton, J. S. \& Ogden, J. C., 1974. Grazing and control of coral reef community structure by Diadema antillarum Philippi (Echinodermata: Echinoidae) a preliminary study. -J. mar. Res. 32, 47-53.

Scatterday, J. W., 1977. Low-water emergence of Caribbean reefs and effect of exposure on coral diversity: observations off Bonaire, Netherlands Antilles. In: Reefs and related carbonateecology and sedimentology. Ed. by S. H. Frost, H. P. Weiss \& J. B. Saunders. Am. Ass. Petr. Geol., Tulsa, 155-169.

Scheer, G., 1966. Bemerkungen über die Strahlungsverhältnisse und über Helligkeitsmessungen im Wasser. - Jenaer Rdsch. 11, 211-218; 263-267.

Scheer, G. \& Pillai, C. S. G., 1974. Report on the Scleractinia from the Nicobar Islands. -Zoologica, Stuttg. 122, 1-75.

Sheppard, C. R. C., 1980. Coral cover, zonation and diversity on reef slopes of Chagos atolls, and population structures of the major species. - Mar. Ecol. Prog. Ser. 2, 193-205.

Sheppard, C. R. C., 1981. Reef and soft substrate coral fauna of Chagos, Indian Ocean. - J. nat. Hist. $15,607-621$.

Sheppard, C. R. C., 1982. Coral populations on reef slopes and their major controls. - Mar. Ecol. Prog. Ser. 7, 83-115.

Siebeck, O., 1981. Photoreactivation and depth-dependent UV tolerance in reef coral in the Great Barrier Reef/Australia. - Naturwissenschaften 68, 426-428.

Stiévenart, J., 1975a. Famille des "Mussidae": 1. Mise en évidence des relations symbiontes-coraux chez les genres Mycetophyllia et Mussa. - Annls Soc. r. zool. Belg. 105, 229-253.

Stiévenart, J., 1975b. Etude de l'association des zooxanthelles avec les polypes des genres Mycetophyllia et Agaricia (Jamaique). - C. r. hebd. Séanc. Acad. Sci., Paris 280, 1603-1606.

Strömgren, T., 1976. Skeleton growth of the hydrocoral Millepora complanata Lamarck in relation to light. - Limnol. Oceanogr. 21, 156-160.

Taylor, D. L., 1978. Nutrition of algal-invertebrate symbiosis. II. Effects of exogenous nitrogen sources on growth, photosynthesis and the rate of excretion by algal symbiont in vivo and in vitro. - Proc. R. Soc. (B) 200, 401-412.

Thiel, M. E., 1932. Madreporaria, zugleich ein Versuch einer vergleichenden Oekologie der gefundenen Formen. - Résult. scient. Voyage Indes orient. néerl. 2, 1-77.

Umbgrove, J. H. F., 1939. Madreporaria from the Bay of Batavia. - Zoöl. Meded., Leiden 22, 1-64.

Umbgrove, J. H. F., 1940. Madreporaria from the Togian reefs (Gulf of Tomini, North Celebes). Zoöl. Meded., Leiden 22, 265-310.

Vaughan, T. W., 1907. Recent madreporaria of the Hawaiian Islands and Laysan. - Bull. U. S. natn. Mus. 49, 1-427.

Vaughan, T. W., 1918. Some shoal-water corals from Murray Island (Australia), Cocos-Keeling Islands, and Fanning Island. - Pap. Dep. mar. Biol. Carnegie Instn Wash. 9, 49-234.

Veron, J. E. N. \& Pichon, M., 1976. Scleractinia of Eastern Australia Pt. I. Families Thamnasteriidae, Astrocoeniidae, Pocilloporidae. - Monogr. Ser. Aust. Inst. mar. Sci. 1, 1-86.

Veron, J. E. N. \& Pichon, M., 1979. Scleractinia of Eastern Australia Pt. III. Families Agariciidae, Siderastreidae, Fungiidae, Oculinidae, Merulinidae, Mussidae, Pectiniidae, Caryophylliidae, Dendrophylliidae. - Monogr. Ser. Aust. Inst. mar. Sci. 4, 1-444.

Veron, J. E. N., Pichon, M. \& Wijsman-Best, M., 1977. Scleractinia of Eastern Australia Pt. II. Families Faviidae, Trachyphylliidae. - Monogr. Ser. Aust. Inst. mar. Sci. 3, 1-233.

Wallace, C. C., 1978. The coral genus Acropora (Scleractinia: Astrocoeniina: Acroporidae) in the Central and Southern Great Barrier Reef Province. - Mem. Qd Mus. 18, 273-319.

Wells, J. W., 1954. Recent corals of the Marshall Islands. - Prof. Pap. U. S. geol. Surv. 260 (1), 385-486.

Wells, J. W., 1971. Note on the Scleractinian corals Scolymia lacera and S. cubensis in Jamaica. Bull. mar. Sci. 21, 960-963.

Wells, J. W., 1973. New and old scleractinian corals from Jamaica. - Bull. mar. Sci. 23, 16-58. 
Wethey, D. S. \& Porter, J. W., 1976. Sun and shade differences in productivity of reef corals. Nature, Lond. 262, 281-282.

Wijsman-Best, M., 1972. Systematics and ecology of New Caledonian Faviinae (Coelenterata Scleractinia). - Bijdr. Dierk. 42, 1-90.

Wijsman-Best, M., 1977. Indo-Pacific coral species belonging to the subfamily Montastreinae Vaughan \& Wells, 1943 (Scleractinia - Coelenterata). Part I. The genera Montastrea and Plesiasirea. - Zoöl. Meded, Leiden 52, 81-97.

Yamazato, K., 1972. Bathymetric distribution of corals in the Ryukyu Islands. In: Proceedings of the symposium of corals and coral reefs. Ed. by C. Mukundan \& C. S. G. Pillai. Mar. Biol. Ass. India, Cochin, 121-133.

Zlatarski, V.N. \& Estalella M. N., 1982. Les scléractiniaires de Cuba. Acad. bulg. Sci., Sofia, 472 pp.

Zvalinsky, V. I., Leletkin, V. A. \& Titliyanov, E. A., 1978. Investigation of the adaptation of coral and symbiotic alga zooxanthellae to the low light intensity in the sea. In: Regularities of distribution and ecology of coastal marine biocenosis. Ed. by O. A. Scarlato \& A. N. Golikov. Nauka, Leningrad, 260. 